\title{
Determination of Healthy Life Style Behaviours of the Students in Middle-Adolescence
}

\author{
Halil Tanır ${ }^{1, *}$ \\ ${ }^{1}$ Faculty of Sport Science, Aydın Adnan Menderes University, Aydın, Turkey \\ *Correspondence: Faculty of Sport Science, Aydın Adnan Menderes University, Aydın, Turkey. E-mail: \\ halil.tanir@adu.edu.tr
}

Received: December 18, 2018

Accepted: January 10, 2019 Online Published: January 21, 2019

doi:10.5430/wje.v9n1p70

URL: https://doi.org/10.5430/wje.v9n1p70

\begin{abstract}
The purpose of this study is to determine healthy life style behaviours, such as average daily sleep duration, sport habit, physical activity level and eating habits, of high school students in their middle adolescence (15-17 ages). The research sample consists of 642 ( $n=338$ male and $n=304$ female) volunteer students in a secondary education institution in Konya city centre. The questionnaire formed by examining relevant literature has been used to determine healthy life style behaviours.

The average daily sleep duration of the students participating in the study is $8.30 \pm 1.26 .42 .8 \%$ the of female students and $37.8 \%$ of the male students do not do sports. $69.8 \%$ of the female students and $74.6 \%$ of the male students use the internet from their mobile phones during the day. The percentage of those who watch television 1-3 hours and more a day is $85.6 \%$ for the female students and $81.6 \%$ for the male students. $28.2 \%$ of the female students and $30.2 \%$ of the male students skip meals. $38.8 \%$ of the female students and $36.1 \%$ of the male students have breakfast.

Within the lights of the findings in the survey, it has been concluded that the students in middle adolescence do not healthy life style behaviours sufficiently. The students do not consume the eatables that are healthy for them. The food stuffs, such as chips, chocolate, carbonated drinks and hamburgers, whose overconsumption is harmful to are frequently consumed by students. It should not be forgotten that the eating habits obtained in the adolescence will affect the adulthood period. Therefore, evaluating their nutritional status, adolescents should be gained adequate and balanced nutrition habits. In the adoption of a healthy lifestyle, adequate balanced nutrition and physical activity should be considered as a whole and, when required, a specialist health professional should be consulted for proper nutritional advice.
\end{abstract}

Keywords: adolescence, student, healthy life style

\section{Introduction}

Adolescent period is a special period in which growing and developing is the fastest and which includes the transition from childhood to adulthood (Demirezen \& Coşansu, 2005). Adolescent period is separated into age groups: early adolescence (11-14 ages), middle adolescence (15-17 ages) and late adolescence (18-21) (Altay et al., 2018).

Health problems experienced in adolescent period may differ in the other periods (Özcebe, 2002). The behaviours which are risky for health are generally acquired in adolescent period. The results of these behaviours can cause significant increases in mortality and morbidity by affecting the adulthood period (Kann et al., 2000). Therefore, the behaviours which are risky for health should be eliminated to adopt a healthy lifestyle, to protect and develop health in adolescence.

Healthy life style behaviours consist of doing enough exercise, balanced diet, not smoking, health responsibility, stress management and hygienic measures. However, in many adolescents, behaviours that are risky for health such as spending more time at the TV or computer, decrease in sleep duration and unbalanced diet are frequently observed nowadays. Thus, it is significant to help individuals adopt the habits of regular sleep, physical activity and balanced diet (İlhan et al., 2010). 
Computers used for communicational and educational purposes have become significant source of entertainment. Among those playing console games, PC games and digital games played online in the virtual world, the number of children and young people has been increasing day by day (Akçay \& Özcebe, 2012). This condition leads to a decrease in physical activity levels of children and adolescents and an increase in the prevalence of obesity. Hence, in parallel with the intense use of computer games, the effects of this situation on children and youth have been questioned (Ferguson, 2007).

Sleep is one of the essential points of adolescent development. Sleep significantly affects the thinking, behaviour and emotional abilities of adolescents. Similarly, daily activities, individual factors, and changes in the environment are also effective on sleep patterns of adolescents (Bootzin \& Stevens, 2005). Children need to sleep and rest sufficiently to achieve their developmental functions (Koulouglioti et al., 2008).

Daily sleeping need of adolescents is more than children and adults. Despite the increased need for sleep, the daily sleeping duration is shortened and many problems can be experienced due to the factors specific to this period (Chervin et al., 2003). Sleeping late at nights and getting up late in the mornings are the sleeping characteristics of this period and there are two important reasons: (a) not being able to sleep adequately due to academic and increasing social activities and (b) the tendency to sleep late and wake up late with increasing age. Furthermore, respiratory system diseases (septal deviation and adenoidal vegetations) frequently seen in childhood and adolescence increase the incidence of sleep disorders. In recent years, the increase in obesity rates seen in this age group has lead to obstructive sleep apnea and correlatively an increase in sleep problems (Li \& Lee, 2009). Sleep problems can range from short-term temporary problems to long-lasting ones and be seen in one out of four children during childhood (Meltzer \& Mindell, 2004). It has been observed that sleep withdrawal increases daytime somnolency and careless behaviours of children and adolescents (Koulouglioti et al., 2008).

Although nutrition is important in every period of life, it has more significance in infancy and childhood when the growth and development process is very fast. If adequate and balanced nutrition cannot be provided at these ages, growth and development decelerates and the whole life of the individual can be adversely affected by various health problems (Erkan et al., 2007).

Necessary nutrients such as protein, fat, carbohydrates, vitamins and minerals which are necessary for adequate and balanced diet are supplied with nutrients. The purpose of nutrition of the child is to provide normal, healthy growth and development. Growth and development are the processes of dynamic alteration of human infant from cellular stage to adulthood. The terms of growth and development contain the processes of physical and mental changes. Thus, the child's body size increases, and the structures and functions of cells, motor and cognitive abilities, sensory, emotional and social behaviours mature. In adolescence, these processes must be overcome healthily. In adolescence, unbalanced and inadequate nutrition create problems and decelerate or stop the development process (Küçükali, 2006). Inaccurate dietary habits can lead to various disorders in children in development period. Very low or very high levels of trace elements can cause toxic effects by disrupting biological functions (Karabiber et al., 2000). Various factors such as the quality of the food, the amount of protein and the total caloric value influence the absorption and metabolism of the elements (Öktem et al., 2005).

The importance of adequate and balanced nutrition with physical activity, sleep quality and adolescence has been understood from all this information in the literature. Thus, the purpose of this study is to determine the sleeping durations, sports habits, time spent at TV or computer, dietary habits which are healthy life style behaviours of the students in middle adolescent period. It has been foreseen that the students can contribute to the process of adopting healthy lifestyle behaviours with the help of the suggestions presented in accordance with the results obtained from the research.

\section{Methods}

\subsection{Participants}

The sample of the study consists of 642 volunteer 9th, 10th and 11th grade students ( $n=338$ male and $n=304$ female) who were at the secondary education school in Konya city centre on the days when the questionnaire was applied.

\subsection{Data Collection Tools}

A questionnaire which was formed examining the sources related to the determination of healthy life style behaviours of the students who participated in the study. The questionnaire form has two parts. The first part contains demographical information ant the second part embraces items related to the time spent at the TV and computer, sports habit, sleeping habit and general dietary habits. 


\section{Results}

Table 1. Gender-Related Average Daily Sleeping Duration of the Students

\begin{tabular}{cccc}
\hline \multicolumn{2}{l}{ Gender } & n & X \pm Sd (hour) \\
\hline \multicolumn{2}{c}{ Female } & 304 & $8.22 \pm 1.25$ \\
& Male & 338 & $8.19 \pm 1.29$ \\
Total & 642 & $8.30 \pm 1.26$ \\
\hline
\end{tabular}

Average daily sleeping duration of the students is $8.30 \pm 1.26$ hours. While the average daily sleeping duration of the female students is $8.22 \pm 1.25$ hours, it is $8.19 \pm 1.29$ in the male students.

Table 2. The Distribution of Gender-Related Frequency of Doing Sports of the Students

\begin{tabular}{lcccc}
\hline \multirow{2}{*}{ Frequency of doing sports } & \multicolumn{3}{c}{ Gender } \\
\cline { 2 - 5 } & \multicolumn{2}{c}{ Female } & $\mathbf{n}$ & Male \\
\cline { 2 - 5 } & $\mathbf{n}$ & $\mathbf{0} .8$ & 128 & $\mathbf{\%}$ \\
\hline None & 130 & 31.9 & 94 & 37.8 \\
1 time per week & 97 & 12.8 & 56 & 27.8 \\
2 times a week & 39 & 6.6 & 32 & 9.6 \\
3-6 times a week & 20 & 5.9 & 28 & 8.5 \\
Every day & 18 & $\mathbf{1 0 0}$ & $\mathbf{3 3 8}$ & $\mathbf{1 0 0}$ \\
Total & $\mathbf{3 0 4}$ & &
\end{tabular}

While $42.8 \%$ of the female students have stated that they do not do sports, $31.9 \%$ of them have indicated that they do sports once a week, $12.8 \%$ twice a week, $6.6 \%$ three-six times a week and $5.9 \%$ every day. While $37.8 \%$ of the male students have stated that they do not do sports, $27.8 \%$ of them have indicated that they do sports once a week, $16.6 \%$ twice a week, $9.5 \%$ three-six times a week and $8.3 \%$ every day.

Table 3. The Distribution of the Students' Spending Time on the Internet with Mobiles by Gender

\begin{tabular}{lcccc}
\hline \multirow{2}{*}{$\begin{array}{l}\text { Spending time on the internet with } \\
\text { mobiles }\end{array}$} & \multicolumn{3}{c}{ Female } & \multicolumn{3}{c}{ Male } \\
\cline { 2 - 5 } & $\mathbf{n}$ & $\mathbf{\%}$ & $\mathbf{n}$ & $\mathbf{0}$ \\
\hline None & 92 & 30.2 & 86 & 25.4 \\
Less than 1 hour per day & 76 & 25.1 & 80 & 23.6 \\
1 hour each day & 58 & 19.1 & 72 & 21.3 \\
2 hours each day & 45 & 14.8 & 55 & 16.2 \\
3 hours each day and more & 33 & 10.8 & 45 & 13.3 \\
Total & $\mathbf{3 0 4}$ & $\mathbf{1 0 0}$ & $\mathbf{3 3 8}$ & $\mathbf{1 0 0}$ \\
\hline
\end{tabular}

While $30.2 \%$ of the female students and $25.42 \%$ of the male students have stated that they do not use the internet with their mobiles all day long, $69.8 \%$ of the female students and $74.6 \%$ of the male students have indicated that they use the internet with their mobiles in a day.

Table 4. The Distribution of the Students' Spending Time at Television by Gender

\begin{tabular}{lcccc}
\hline \multirow{2}{*}{ Spending time at television } & \multicolumn{3}{c}{ Female } & \multicolumn{3}{c}{ Male } \\
\cline { 2 - 5 } & $\mathbf{n}$ & $\mathbf{\%}$ & $\mathbf{n}$ & $\mathbf{\%}$ \\
\cline { 2 - 5 } & 8 & 2.6 & 14 & 4.14 \\
None & 36 & 11.8 & 48 & 14.3 \\
Less than 1 hour per day & 32 & 10.6 & 56 & 16.5 \\
1 hour each day & 90 & 29.6 & 94 & 27.8 \\
2 hours each day & 138 & 45.4 & 126 & 37.3 \\
3 hours each day and more & $\mathbf{3 0 4}$ & $\mathbf{1 0 0}$ & $\mathbf{3 3 8}$ & $\mathbf{1 0 0}$ \\
Total & & &
\end{tabular}


It has been observed that the percentage of the students who watch television is $2.6 \%$ in the females and $4.14 \%$ in the males. $11.8 \%$ of the female students and $14.3 \%$ of the male students watch television at least one hour every day. The percentage of those who watch television for $1-3$ hours and more is $85.6 \%$ in the female students and $81.6 \%$ in the male students.

Table 5. The Distribution of the Students' Skipping a Meal by Gender

\begin{tabular}{lccccc}
\hline & \multicolumn{5}{c}{ Gender } \\
\cline { 2 - 6 } Skipping a meal & $\mathbf{n}$ & Female & $\mathbf{0}$ & Male & $\mathbf{\%}$ \\
\cline { 2 - 5 } & 86 & 28.2 & 102 & 30.2 \\
\hline Yes I skip a meal & 218 & 71.8 & 236 & 69.8 \\
No I don't skip a meal & $\mathbf{3 0 4}$ & $\mathbf{1 0 0}$ & $\mathbf{3 3 8}$ & $\mathbf{1 0 0}$ \\
Total & &
\end{tabular}

It has been determined that 28.2 of the female students and $30.2 \%$ of the male students skip a meal. It has also been detected that the percentage of those who do not skip a meal is $71.8 \%$ in the females and $69.8 \%$ in the females.

Table 6. The Distribution of the Students' Having Breakfast by Gender

\begin{tabular}{lcccc}
\hline \multirow{2}{*}{$\begin{array}{l}\text { Frequency of } \\
\text { having breakfast }\end{array}$} & \multicolumn{3}{c}{ Female } & \multicolumn{3}{c}{ Gender } \\
\cline { 2 - 5 } & $\mathbf{n}$ & $\mathbf{\%}$ & $\mathbf{n}$ & $\mathbf{\%}$ \\
\hline Every day & 118 & 38.8 & 122 & 36.1 \\
4-6 times a week & 106 & 34.8 & 117 & 34.6 \\
2-3 times a week & 72 & 23.6 & 78 & 23.2 \\
None & 18 & 5.9 & 21 & 6.3 \\
Total & $\mathbf{3 0 4}$ & $\mathbf{1 0 0}$ & $\mathbf{3 3 8}$ & $\mathbf{1 0 0}$ \\
\hline
\end{tabular}

While $38.8 \%$ of the female students and $36.1 \%$ of the male students have breakfast every day, $5.9 \%$ of the female students and $6.3 \%$ of the male students do not have breakfast. The percentage of those who have breakfast twice- six times a week is $58.4 \%$ in the females and $57.8 \%$ in the males.

$96.6 \%$ of the students consume fruit and $90.7 \%$ of them consume vegetables. While the percentage of those who do not drink $100 \%$ ready fruit juice is $23.7 \%$, the percentage of those who do not drink fresh-squeezed fruit juice is $37.6 \%$. $39.0 \%$ of the students do not consume sugared fizzy drinks and $81.4 \%$ of them do not consume dietary fizzy drinks. The percentages of milk consumption of the students are as follows: $33.0 \%$ of them consume skimmed/semi skimmed milk, $24.1 \%$ whole-fat milk and $48.3 \%$ aromatized milk. The percentages of dairy products consumption of the students are: $87.5 \%$ of them cheese, $94.7 \%$ ayran, $93.8 \%$ yoghurt and $74.7 \%$ milky pudding. $6.1 \%$ of the students do not consume eatables such as red meat, chicken, turkey and $22.7 \%$ of them do not consume fish. $92.9 \%$ of the students consume eggs and 92.8 of them consume legume. Of the students, $8.1 \%$ do not consume dried fruits; $1.2 \%$ cereals like bread; $20.3 \%$ of chips, popcorn; $8.8 \%$ biscuits, cakes, cookies, pastry etc.; $14.2 \%$ food stuffs such as pita, Turkish pizza, French fries and hamburgers.

\section{Discussion and Conclusion}

Even though being healthy is one of the fundamental rights of each human being, it is also one's own responsibility to provide and maintain it as well as being a primary aim of health personnel. In order to adopt health enhancing behaviours, individuals must check themselves and be enthusiastic to adopt these behaviours. Because it is necessary to adopt and maintain positive health behaviours to improve health (illhan et al., 2010). Therefore, it is important in terms of public health to examine healthy lifestyle behaviours of middle adolescent students and to support them in the topics they have deficiency. Of the students who have participated in this study conducted in order to determine the healthy lifestyle behaviours of high school students in the middle adolescent period, $52.6 \%(\mathrm{n}=338)$ are male and $47.4 \%(n=304)$ are female. The students' age average is $17.16 \pm 1.08$ and while the youngest is 14 , the eldest is 19 years old. 
Table 7. The Frequency of the Students' Consumption of Some Nutrition and Drinks

\begin{tabular}{|c|c|c|c|c|}
\hline Nutrients & Every day & $\begin{array}{c}\text { 4-6 times } \\
\text { a week }\end{array}$ & $\begin{array}{c}\text { 1-3 times } \\
\text { a week }\end{array}$ & None \\
\hline Fruit & 40.8 & 25.3 & 30.5 & 3.4 \\
\hline Vegetables & 21.3 & 23.3 & 46.2 & 9.3 \\
\hline $100 \%$ ready fruit juice & 15.2 & 12.9 & 48.2 & 23.7 \\
\hline Fresh-squeezed fruit juice & 6.8 & 10.5 & 45.0 & 37.6 \\
\hline Sugared fizzy drinks & 5.2 & 7.5 & 48.3 & 39.0 \\
\hline Dietary fizzy drinks & 2.7 & 3.2 & 12.7 & 81.4 \\
\hline Skimmed/semi skimmed milk & 21.6 & 17.4 & 28.0 & 33.0 \\
\hline Whole-fat milk & 29.9 & 17.1 & 28.9 & 24.1 \\
\hline Aromatized milk & 7.3 & 7.8 & 36.6 & 48.3 \\
\hline Cheese & 52.0 & 15.5 & 20.1 & 12.5 \\
\hline Ayran & 29.7 & 24.7 & 40.2 & 5.3 \\
\hline Yoghurt & 38.9 & 24.9 & 30.0 & 6.2 \\
\hline Milky pudding & 4.9 & 12.6 & 57.2 & 25.3 \\
\hline Red meat, chicken, turkey & 10.8 & 29.1 & 54.0 & 6.1 \\
\hline Fish & 3.1 & 10.2 & 64.0 & 22.7 \\
\hline Eggs & 40.4 & 30.1 & 22.4 & 7.1 \\
\hline Consume dried fruits & 6.8 & 29.6 & 56.4 & 7.2 \\
\hline Nuts & 14.8 & 22.7 & 58.6 & 8.1 \\
\hline Cereals like bread & 47.1 & 30.4 & 21.3 & 1.2 \\
\hline Chips, popcorn & 7.7 & 14.4 & 57.6 & 20.3 \\
\hline Chocolate bars & 16.4 & 20.0 & 54.8 & 8.8 \\
\hline Biscuits, cakes, cookies, pastry etc. & 18.5 & 28.2 & 49.6 & 3.7 \\
\hline Pita, pizza and hamburgers & 5.2 & 11.6 & 69.1 & 14.2 \\
\hline
\end{tabular}

The average of daily sleeping duration of the students has been determined to be $8.30 \pm 1.26$ hours. The average of daily sleeping duration of the female students is $8.22 \pm 1.25$ hours and it is $8.19 \pm 1.29$ hours in the male students (Table 1). Karadağ (2007) states that the need for sleep can vary according to age; adults should sleep 7-9 hours per day, teenagers from 13 to adulthood should sleep 8.5-9.5 hours and children between 5-12 should sleep 9-11 hours. Accordingly, it can be claimed that the sleeping duration of the students who participated in the research is not enough. In the study conducted in Republic of China, Xu et al. (2012) found that the sleep quality of the adolescents aged 16-20 years was poor at the rate of 20\%. Tekeli (2009) evaluated that the sleeping quality of high school senior students as $28.2 \%$ good and $71.8 \%$ poor. Şenol et al. (2012) reported in their study that $54.7 \%$ of adolescents had low sleep quality and $9 \%$ of them complained about excessive somnolency.

In the study, it has been indicated that $42.8 \%$ of the female students and $37.8 \%$ of the male students do not do sports (Table 2). Bebiş et al. (2015) reported that the female students' exercise subscale scores were lower than the male students' scores in their study in which they examined the health enhancing behaviours of adolescents in a secondary school. In their study in which they search for the factors affecting healthy life style of high school students, Sümen and Öncel (2017) reported that most of those who state that they never do exercises are the females and the ones who do exercises regularly are mostly the males. In a similar study, Aksoydan and Çakır (2011) stated that the habit of doing sports of the males is more than the females'. Akman et al. (2012) reported that approximately half of the adolescents participated in the study joined in a regular sport activity while the average physical activity per week was 2.05 .

$69.8 \%$ of the female students and $74.6 \%$ of the male students stated that they used the internet with their mobiles during the day (Table 3). In the studies conducted all over the world, the prevalence of problematic internet use among adolescents and young adults has been observed to range from $0.9 \%$ to $38 \%$. Especially in European adolescents, the prevalence of problematic internet use varies between $2 \%$ and $5.4 \%$ (Kormas et al., 2011). The incidence of internet addiction in adolescents has been estimated to be approximately $11 \%$ in China, $8 \%$ in Greece and $18.4 \%$ in Korea (Kim et al., 2010). When the studies on the internet addiction of high school students in Turkey have been examined, it has been observed that the prevalence of internet addiction varies between $6.6 \%$ and $15 \%$ (Öztürk et al., 2013; Şaşmaz et al., 2013). Chisholm (2006) stated that children and adolescents between 8 and18 spend an average of 8 hours a day using information and communication devices. Berson and Berson (2003) reported 
that $74 \%$ of young girls, especially $12-18$ years old, spent most of their time in virtual chat rooms or massaging with e-mails. In the study conducted in the United States, it was found that $89 \%$ of the youth used computers and $61 \%$ of them surfed in the Internet (Strasburger \& Donnerstein, 1999). In some studies, it was determined that young people aged between 13 and 19 years were more intense internet users than their parents (Colwell \& Kato 2003; Kubey et al., 2001). In the study Kelleci et al. (2009) did on 673 high school students, it was determined that there was a statistically significant difference between girls and boys in terms of internet usage period according to gender; $70.2 \%$ of the female students and $60.2 \%$ of the male students used the internet 1-2 hours in a day and the percentage of the internet usage for 5 hours or more in a day was higher (16.8\%) in the male students. In the study conducted Liau et al. (2005) stated that men used the internet more than girls did and the aims of men's internet usage were different than girls said.

In the study, the rate of those watching television for 1-3 hours and more is $85.6 \%$ in the female students and $81.6 \%$ in the male students (Table 4). The adolescent participants of the study by Akman et al. (2012) remarked that on a day, they spared time to watch television for average $2.32 \pm 1.54$ hours, $1.52 \pm 0.98$ hours to watch DVD, video or movies in a cinema, $1.17 \pm 0.95$ hours to read books or newspapers, $2.43 \pm 1.70$ hours to spend time at computer, to play game or to use the internet and $2.51 \pm 1.20$ hours to study. In the study conducted among high school students, it was found that $42.8 \%$ of the students watched television for more than two hours in one day and $13.9 \%$ of them watched television for at least five hours. The studies conducted in the United States indicated that children watch television on average 21-28 hours a week (Lowry et al., 2002).

It has been determined that $28.2 \%$ of female students and $30.2 \%$ of male students skipped meals (Table 5 ). In adolescents, it has been observed that skipping a meal is common, especially in the middle and late adolescence. It has been remarked that the most frequent skipped meal is breakfast. Among the reasons for skipping breakfast, the reasons such as to sleep more in the mornings, lack of time, inappetency, lack of food and diet have been indicated (Stang \& Story, 2005). It has been stated that $81 \%$ of the high school students participating in the study by Türk et al. (2007) skipped a meal, the most frequent skipped meal was breakfast with the rate of $45.6 \%$ and then lunch followed with the rate of $39.8 \%$. In his study with high school students Karasu (2006) found that $55.7 \%$ of the students skipped meals, $27.3 \%$ of them skipped breakfast and $15.0 \%$ of them skipped lunch. While $38.8 \%$ of the female students and $36.1 \%$ of the male students have breakfast, $5.9 \%$ of the female students and $6.3 \%$ of the male students do not have breakfast. The rate of the students who have breakfast $2-6$ times a week is $58.4 \%$ in the females and $57.8 \%$ in the males (Table 6). It has been reported that the percentage of the adolescents with the habit of having breakfast was $87-94 \%$ in Portugal, $88 \%$ in Spain in 3-16 age group, 56.4\% in Netherlands in $12-15$ age group and $78 \%$ in Italy in 6-14 age group (DeJong et al., 2009). Özmen et al. (2007) reported that the rate of the high school students having breakfast was $66 \%$. In another study conducted with high school students, it was found that $60.7 \%$ of the students had breakfast regularly, 20.2\% had breakfast sometimes and 19.1\% never had breakfast (Önder et al., 2000). Mazıcıoğlu and Öztürk (2003) indicated that $34.4 \%$ of the students had breakfast regularly every day and $65.6 \%$ of them rarely or never had breakfast.

In the study, it has been determined that the percentage of those who do not drink $100 \%$ ready fruit juice is $23.7 \%$ and the percentage of those who do not drink fresh-squeezed fruit juice is $37.6 \%$. 39.0\% of the students do not consume sugared fizzy drinks and $81.4 \%$ of them do not consume dietary fizzy drinks (Table 7 ). In his study Kaşıkçı (2010) indicated that $88.7 \%$ of the students consumed nutrients between meals and these were generally nutrients such as cola and juice. Among the nutrients consumed by the adolescents in the Konya orphanage, while bagels, biscuits and cookies were in the first place, starched drinks were in the second and sugar, chocolate wafers were in third place (Kayhan et al., 2000).

$96.6 \%$ of the students consume fruit and 90.7 of them consume vegetables (Table 7). Among the high school students in Kocaeli province, it has been found that the rate of those who did not eat any fruit in the last seven days or who ate less than one fruit in a day was $45.4 \%$, the rate of those who did not eat green salad or who ate less than one green salad in a day was $53.6 \%$ and the rate of those who didn't drink any milk or those who drank less than one glass of milk in a day was $68.1 \%$ (Kara et al., 2003). In their study Türk et al. (2007) stated that students with high nutritional information prefer to consume nutrients such as fruit, milk / yoghurt and salads more than those such as tea, chocolate, ready-made cakes / biscuits. The study conducted in Ankara indicated that the students consume milk and dairy products every day. Meat consumption mostly varies from once- twice a week to once-twice a month.

$92.9 \%$ of the students participating in the study consume eggs (Table 7). Approximately half of the students participating in the study done by Kara et al. (2003) consume eggs once or twice a week and fruit and vegetables every day. 
$14.2 \%$ of the students do not consume eatables like pita, Turkish pizza, French fries, hamburger (Table 7). In the study, Kaşıkçı (2010) determined that 76.8 of the students consumed fast food. It has been stated that the rate of fast food consumption was $81.4 \%$ among the students participating in the study done by Tanriverdi et al. (2011).

In the light of the findings obtained in the study, it has been concluded that the students in the middle adolescent period did not have enough healthy lifestyle behaviours. Average daily sleeping duration of the students is insufficient. The use of the internet with the mobiles and the behaviour of spending time at television during the day are quite common among students. A considerable amount of the students skip a meal; more than half of the students do not have breakfast. The students do not consume healthful nutrients sufficiently. The nutrients such as chips, chocolate, fizzy drinks and hamburgers whose intensive consumption is harmful have been frequently consumed by the students.

Unwanted behaviours such as obesity due to a life style which is inactive and nonsporing, faulty diets which are followed to look slimmer with the guidance of media, adopted malnutrition habits, insufficiency of the intake of energy and nutritional elements and going to school skipping breakfast may affect the adolescents, who are still in upbringing period, in ill part. All these negative behaviours lead to many chronic diseases such as obesity, cardiovascular diseases, cancer and diabetes. Obesity has become a significant problem for adolescents with the increase in the consumption of fast food, chips, sugared food and drinks and with the extension of the inactive time spent at television and computer.

It should not be forgotten that the dietary habits adopted during adolescence will influence the adulthood period. Therefore, sufficient and balanced diet habits should be adopted by evaluating the nutritional status of adolescents. In the adoption of a healthy lifestyle, adequate balanced nutrition and physical activity should be considered as a whole and expert health personnel should be consulted when it is necessary.

\section{References}

Akman, M., Tüzün, S., \& Ünalan, P.C. (2012). Adolesanlarda sağlıklı beslenme ve fiziksel aktivite durumu. Nobel Medicus Journal, 8(1), 24-29.

Altay, M., Cabar, H.D., \& Altay, B. (2018). Adolesan dönemi çocuklarda beslenme ve okul sağlı̆̆. Sinop Üniversitesi Sosyal Bilimler Dergisi, 2(3), 173-180. https://doi.org/10.30561/sinopusd.414093

Bebiş, H., Akpunar, D., Özdemir, S., \& Kılıç, S. (2015). Bir ortaöğretim okulundaki adolesanların sağlığı geliştirme davranışlarının incelenmesi. Gülhane Tıp Dergisi, 57, 129-135.

Berson, I.R., \& Berson, M.J. (2003). Digital literacy for effective citizenship. (Advancing Technology). Social Education, 67(3), 164-168.

Bootzin, R.R., \& Stevens, S.J. (2005). Adolescents, substance abuse, and the treatment of insomnia and daytime sleepiness. Clinical Psychology Review, 25(5), 629-644.

Chervin, R.D., Dillon, J.E., Archbold, K.H., \& Ruzicka, D.L. (2003). Conduct problems and symptoms of sleep disorders in children. Journal of the American Academy of Child \& Adolescent Psychiatry, 42(2), 201-208. https://doi.org/10.1097/00004583-200302000-00014

Chisholm, J.F. (2006). Cyberspace violence against girls and adolescent females. Annals of the New York Academy of Sciences, 1087(1), 74-89. https://doi.org/10.1196/annals.1385.022

Colwell, J., \& Kato, M. (2003). Investigation of the relationship between social isolation, self - esteem, aggression and computer game play in Japanese adolescents. Asian Journal of Social Psychology, 6(2), 149-158. https://doi.org/10.1111/1467-839X.t01-1-00017

DeJong, C. S., Van Lenthe, F. J., van der Horst, K., \& Oenema, A. (2009). Environmental and cognitive correlates of adolescent breakfast consumption. Preventive Medicine, 48(4), 372-377. https://doi.org/10.1016/j.ypmed.2009.02.009

Demirezen, E., \& Coşansu, G. (2005). Adolesan çağı öğrencilerde beslenme alışkanlıklarının değerlendirilmesi. Sürekli Tip Eğitimi Dergisi, 14(8), 174-178.

Erkan, T., Yalvaç, S., Erginöz, E., Çokuğraş, F., \& Kutlu, T. (2007). İstanbul Üniversitesi Cerrahpaşa Tip Fakültesi Çocuk Yuvasındaki çocukların beslenme durumlarının antropometrik ölçümlerle değerlendirilmesi. Türk Pediatri Arşivi, 42(4), 142-47.

Ferguson, C.J. (2007). The good, the bad and the ugly: A meta-analytic review of positive and negative effects of 
violent video games. Psychiatric Quarterly, 78(4), 309-316.

İlhan, N., Batmaz, M., \& Akhan, L.U. (2010). Üniversite öğrencilerinin sağlıklı yaşam biçimi davranışları. Maltepe Üniversitesi Hemşirelik Bilim ve Sanatı Dergisi, 3(3), 34-44.

Kara, B., Hatun, Ş., Aydoğan, M., Babaoğlu, K., \& Gökalp, A. S. (2003). Kocaeli ilindeki lise öğrencilerinde sağllk açısından riskli davranışların değerlendirilmesi. Çocuk Sağlı̆̆ı ve Hastalıkları Dergisi, 46(1), 30-37.

Karabiber, H., Özgen, Ü., Özcan, C., Soylu, H., Kutlu, O., Sarıbaş, S., \& Kaya, M. (2000). Demir eksikliği anemili çocuklarda tedavinin mental skor ve uyarılmış potansiyellere etkisi. Türk Hematoloji Onkoloji Dergisi, 10(4), 194-198.

Karadağ, M. (2007). Uyku bozuklukları sinıflaması (ICSD-2). Turkiye Klinikleri Archives of Lung, 8(3), 88-91.

Karasu, Ö. (2006). Yatılı Olan ve Yatılı Olmayan Lise Öğrencilerinin Beslenme Bilgisi ve Durumlarının Değerlendirilmesi. Gazi Üniversitesi Eğitim Bilimleri Enstitüsü, Aile Ekonomisi ve Beslenme Eğitimi Anabilim Dalı, Yüksek Lisans Tezi, Ankara.

Kaşıkçı, S. (2010). Edirne İli Merkez İlköğretim Okullarında Okuyan 6., 7. ve 8. Sinıf Öğrencilerinin Beslenme Alışkanlıkları Üzerine Bir Araştırma. Namık Kemal Üniversitesi Fen Bilimleri Enstitüsü, Gıda Mühendisliği Anabilim Dalı, Yüksek Lisans Tezi, Tekirdağ.

Kayhan, E.Ş., \& Şahin, T. K. (2000). Konya'da iki yetiştirme yurdunda barınan adolesanların beslenme durumları. Beslenme ve Diyet Dergisi, 29, 25-33.

Kelleci, M., Güler, N., Sezer, H., \& Gölbası, Z. (2009). Lise öğrencilerinde internet kullanma süresinin cinsiyet ve psikiyatrik belirtiler ile ilişkisi. TAF Preventive Medicine Bulletin, 8(3), 223-230.

Kim, Y., Park, J.Y., Kim, S.B., Jung, I.K., Lim, Y.S., \& Kim, J.H. (2010). The effects of Internet addiction on the lifestyle and dietary behavior of Korean adolescents. Nutrition Research and Practice, 4(1), 51-57. https://doi.org/10.4162/nrp.2010.4.1.51

Kormas, G., Critselis, E., Janikian, M., Kafetzis, D., \& Tsitsika, A. (2011). Risk factors and psychosocial characteristics of potential problematic and problematic internet use among adolescents: A cross-sectional study. BMC Public Health, 11(1), 595-602. https://doi.org/10.1186/1471-2458-11-595

Koulouglioti, C., Cole, R., \& Kitzman, H. (2008). Inadequate sleep and unintentional injuries in young children. Public Health Nursing, 25(2), 106-114. https://doi.org/10.1111/j.1525-1446.2008.00687.x

Kubey, R.W., Lavin, M. J., \& Barrows, J.R. (2001). Internet use and collegiate academic performance decrements: Early findings. Journal of Communication, 51(2), 366-382.

Küçükali, R. (2006). Çocuklarda beslenme bozuklukları ve beslenmenin okul çocuklarının üzerindeki etkileri. Atatürk Üniversitesi Kazım Karabekir Eğitim Fakültesi Dergisi, 14, 223-239.

Li, H.Y., \& Lee, L.A. (2009). Sleep-disordered breathing in children. Chang Gung Med J., 32(3), 247-57.

Liau, A.K., Khoo, A., \& Hwaang, P. (2005). Factors influencing adolescents engagement in risky internet behavior. Cyber Psychology \& Behavior, 8(6), 513-520. https://doi.org/10.1089/cpb.2005.8.513

Lowry, R., Wechsler, H., Galuska, D. A., Fulton, J. E., \& Kann, L. (2002). Television viewing and its associations with overweight, sedentary lifestyle, and insufficient consumption of fruits and vegetables among US high school students: Differences by race, ethnicity, and gender. Journal of School Health, 72(10), 413-421. https://doi.org/10.1111/j.1746-1561.2002.tb03551.x

Meltzer, L.J., \& Mindell, J.A. (2004). Nonpharmacologic treatments for pediatric sleeplessness. Pediatric Clinics of North America, 51(1), 135-151. https://doi.org/10.1016/S0031-3955(03)00178-0

Öktem, F., Yavrucuoğlu, H., Türedi, A., \& Tunç, B. (2005). Çocuklarda beslenme alışkanlıklarının hematolojik parametreler ve eser elementler üzerine etkisi. SDÜ Tip Fakültesi Dergisi, 12(1), 6-10.

Önder, F.O., Kurdoğlu, M., Oğuz, G., Özben, B., Atilla, S., \& Oral, S.N. (2000). Gülveren Lisesi son sinıf öğrencilerinin bazı beslenme alışkanlıklarının saptanması ve bunun malnütrisyon prevalansı ile olan ilişkisi. Hacettepe Toplum Hekimliği Bülteni, 21(1), 12-18.

Özcebe, H. (2002). Birinci basamakta adolesan sorunlarına yaklaşım. Sürekli Tıp Eğitimi Dergisi, 11(10), 374-377.

Özmen, D., Çetinkaya, A. Ç., Ergin, D., Şen, N., \& Erbay, P.D. (2007). Lise öğrencilerinin yeme alışkanlıkları ve beden ağırlığını denetleme davranışları. TSK Koruyucu Hekimlik Bülteni, 6(2), 98-105. 
Özturk, F.O., Ekinci, M., Özturk, O., \& Canan, F. (2013). The relationship of affective temperament and emotional-behavioral difficulties to internet addiction in Turkish teenagers. ISRN Psychiatry, 2013. https://doi.org/10.1155/2013/961734

Stang, J., \& Story, M.T. (2005). Guidelines for adolescent nutrition services (p. 93). Center for Leadership, Education and Training in Maternal and Child Nutrition.

Strasburger, V.C., \& Donnerstein, E. (1999). Children, adolescents, and the media: Issues and solutions. Pediatrics, 103(1), 129-139. https://doi.org/10.1542/peds.103.1.129

Şaşmaz, T., Öner, S., Kurt, A.Ö., Yapıcı, G., Yazıcı, A.E., Buğdaycı, R., \& Şiş, M. (2013). Prevalence and risk factors of Internet addiction in high school students. The European Journal of Public Health, 24(1), 15-20. https://doi.org/10.1093/eurpub/ckt051

Şenol, V., Soyuer, F., Akça, R.P., \& Argün, M. (2012). Adolesanlarda uyku kalitesi ve etkileyen faktörler. Kocatepe Tip Dergisi, 13(2), 93-101.

Tanrıverdi, D., Savaş, E., Gönüllüoğlu, N., Kurdal, E., \& Balık, G. (2011). Lise öğrencilerinin yeme tutumları, yeme davranışları ve benlik saygılarının incelenmesi. Gaziantep Medical Journal, 17(1), 33-39.

Tekeli, S. (2009). Lise Son Sinıf Öğrencilerinin Uyku Kalitelerinin Ve Sinav Kaygılarının Değerlendirilmesi. Marmara Üniversitesi Sağlık Bilimleri Enstitüsü, Çocuk Sağlığı ve Hastalıkları Hemşireliği Anabilim Dalı, Yüksek Lisans Tezi, İstanbul.

Türk, M., Gürsoy, Ş. T., \& Ergin, I. (2007). Kentsel bölgede lise birinci sınıf öğrencilerinin beslenme alışkanlıkları. Genel Tip Dergisi, 17(2), 81-87.

Xu, Z., Su, H., Zou, Y., Chen, J., Wu, J., \& Chang, W. (2012). Sleep quality of Chinese adolescents: Distribution and its associated factors. Journal of Paediatrics and Child Health, 48(2), 138-145. https://doi.org/10.1111/j.1440-1754.2011.02065.x 